\title{
Compensatory cleaner-seeking behavior following spawning in female yellowtail damselfish
}

\author{
Paul C. Sikkel ${ }^{1,4, *}$, Steven E. Herzlieb ${ }^{2}$, Donald L. Kramer ${ }^{3}$ \\ ${ }^{1}$ Bellairs Research Institute of McGill University, St. James, Barbados \\ ${ }^{2}$ Center for Marine and Environmental Studies, University of the Virgin Islands, St. Thomas 00802, US Virgin Islands \\ ${ }^{3}$ Department of Biology, McGill University, 1205 Docteur Penfield Avenue, Montreal, Quebec H3A 1B1, Canada
}

${ }^{4}$ Present address: Department of Biology, Murray State University, 334 Blackburn Hall, Murray, Kentucky 42071-0009, USA

ABSTRACT: Marine reef fishes may spend a significant proportion of their daily activity budgets visiting cleaning stations. Nevertheless, the roles of ectoparasites and of interactions with cleaners in shaping patterns of diel activity in these fishes have been largely ignored, possibly because the importance of cleaning for the hosts remains controversial. In diurnal species, a peak in ectoparasite infestation exists at dawn, suggesting that higher rates of cleaner-seeking during this time should be beneficial to hosts. In this study, we quantified the diel pattern of visitations to cleaners, as well as other major activities, in female yellowtail damselfish Microspathodon chrysurus on a Barbadian fringing reef. Females of this species leave their territories near dawn at 3 dintervals to spawn on male territories. On non-spawning days, cleaning peaked at dawn, when fish spent $>20 \%$ of their time with cleaners, and declined thereafter, averaging over $11 \%$ of the time budget during the entire day. Supplemental observations in Puerto Rico and the Virgin Islands also revealed dawn peaks in cleaner-seeking activity. Feeding and territory defense together occupied less than $3 \%$ of the time budget at dawn, and never seemed frequent enough to interfere with cleaning. On spawning days, 30\% of females visited cleaners at male nests or while traveling back to their territories, and $24 \%$ visited cleaners on their own territories during revisitation trips before spawning was completed; nevertheless, they spent $<1 / 3$ as much time with cleaners as did non-spawning females. Reduced cleanerseeking indicates that spawning competes with cleaner visitation in damselfish time budgets, producing a tradeoff between cleaning and reproduction. In the $30 \mathrm{~min}$ after spawning, females significantly increased their rate of interaction with cleaners, compared with the same time on nonspawning days, and regained about $68 \%$ of the missed time with cleaners; feeding and aggression did not differ between spawning and non-spawning females. Compensatory postspawning visiting of cleaners supports the hypothesis that cleaning at dawn is important, probably because of negative consequences of the dawn peak in parasite loads.

KEY WORDS: Cleaning · Symbiosis · Diel activity cycles · Ectoparasite $\cdot$ Coral reef fish · Pomacentridae - Spawning

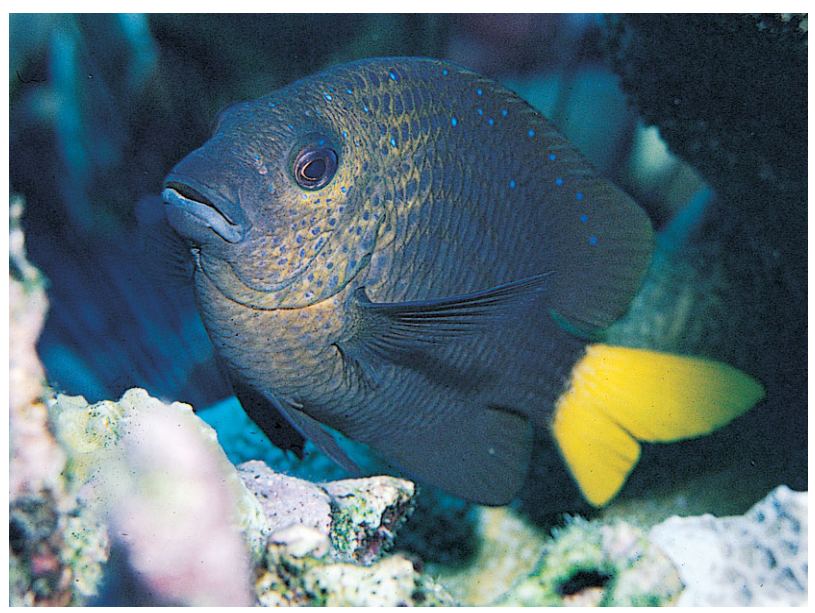

A yellowtail damselfish Microspathodon chrysurus hovers near the coral substratum in a posture typical of fish visiting cleaner shrimps and gobies that remove ectoparasites. Photo @ 2005 Paul Humann/Marinelifeimages.com. Used by permission

\section{INTRODUCTION}

Cleaning is one of the most conspicuous activities on tropical reefs and has been studied for $>5$ decades (reviewed by Poulin 1993, Poulin \& Grutter 1996, Côté 2000). Fishes visiting cleaning stations hover near the substratum or 'pose' in a head-up or head-down posture in the water column (Losey 1971, Côté et al. 1998), often waiting in aggregations, where cleaners inspect and often remove ectoparasites or tissue from them (e.g. Youngbluth 1968, Grutter 1996a). These observations have led to the hypothesis that being cleaned provides an important fitness advantage to host fishes through removal of parasites and is therefore adaptive. 
Because of the difficulty of performing long-term field experiments in which multiple components of fitness are measured and thus net benefits of being cleaned are determined (Grutter 1996b, Cheney \& Côté 2003a), tests of this hypothesis have focused mostly on indicators of short-term benefits. For example, there is evidence for a deleterious effect on hosts of the most common ectoparasite removed by cleaners (see below), and recent studies have found a significant reduction in these parasites by cleaners at sites on the Great Barrier Reef and the Eastern Caribbean (Grutter 1999, Cheney \& Côté 2001). However, some earlier studies in the tropical Pacific found no net reduction of host parasite loads by cleaners (Youngbluth 1968, Losey 1972, Gorlick et al. 1987), leading to the alternative hypothesis that cleaners may act as parasites that gain access to food by exploiting the client's propensity to seek rewarding tactile stimulation (e.g. Losey \& Margules 1974, Losey 1979).

The hypothesis that removal of parasites is an adaptive function of visiting cleaning stations predicts that cleaning (1) should comprise a significant part of the daily activity budget of host fish and (2) should occur most when the benefits of parasite removal are greatest, relative to the cost of visiting cleaners. These predictions have received support from behavioral studies of host fish. For example, on the Great Barrier Reef, more highly parasitized species tend to spend more time with cleaners (Grutter 1995). In Barbados, the proportion of time spent with cleaners is positively correlated with sex- and location-dependent ectoparasite loads among individual yellowtail Microspathodon chrysurus and longfin Stegastes diencaeus damselfish, and negatively correlated with travel distance to cleaning stations in the latter species (Sikkel et al. 2000, Cheney \& Côté 2001, 2003b).

More recent studies have focused on diel variation in activity of gnathiid isopods, the most common crustacean ectoparasite on tropical reef fishes. Gnathiid isopods are generalist parasites, but they are only parasitic as larvae and are the most common food item of cleaner fishes in both Caribbean and tropical IndoPacific reefs (Grutter 1996a, Arnal \& Côté 2000). These highly mobile ectoparasites emerge from the substratum throughout the day and night to find a host and, when engorged on blood and body fluids, return to the substratum to moult into the next larval stage (Smit et al. 2003). The amount of time required by gnathiids to become engorged with host fluids appears to range from 1 to $3 \mathrm{~h}$ for first and second stage larvae, and to up to $10 \mathrm{~h}$ for third stage larvae (Grutter 2003, Smit et al. 2003). Gnathiid bites damage branchial tissue (Honma \& Chiba 1991, Heupel \& Bennett 1999) and may transmit coccidia (Davies 1982) and possibly bacteria (Honma \& Chiba 1991). In large numbers, they reduce hematocrit levels (Jones \& Grutter 2005), and even cause death in captive fishes (Paperna \& Por 1977, Mugridge \& Stallybrass 1983).

In the Eastern Caribbean, daytime emergence rates of gnathiids are highest at dawn, lowest during the middle of the day, and sometimes increase again during the late afternoon and at dusk (Chambers \& Sikkel 2002, Sikkel et al. 2004). Cleaner fishes and many host species are inactive at night. Thus, wild-caught fishes of diurnally active species have highest numbers of gnathiids at dawn, followed by dusk, compared with other times of day, with average levels at dawn being 50 to $400 \%$ higher than at midday (Côté \& Molloy 2003, Sikkel et al. 2004). Even stronger dawn peaks, but no increase at dusk, have been found on caged fish prevented from visiting cleaners (P. C. Sikkel unpubl. data). Dawn peaks in ectoparasite loads have also been reported on the Great Barrier Reef (Grutter 1999, Grutter \& Hendrikz 1999).

Given a peak of infestation in the early morning, and the increasing likelihood of injury or disease transmission with duration of attachment, one would expect a peak in the benefit of visiting cleaning stations as soon as diurnal fishes become active. This is because such visits would remove the greatest number of parasites and perhaps reduce total tissue damage and loss of blood, compared to waiting until later in the day. There was no evidence, however, for a dawn peak in cleaning station visits in Grutter et al.'s (2002) study of thick-lipped wrasse Hemigymnus melapterus on the Great Barrier Reef. In contrast, dawn-to-dusk surveys of a variety of species in Puerto Rico, Eastern Caribbean, found more fish at cleaning stations at dawn than at any other time of day (Chambers \& Sikkel 2002), although each time of day was replicated only once. Côté \& Molloy (2003) noted a nearly significant tendency among 5 species in Barbados to 'pose' more often during the early morning visits to cleaning stations than during midday or late afternoon visits, although frequency of visits did not vary significantly over the daily cycle. In a more recent study on longfin damselfish comparing 5 time periods, the proportion of time spent with cleaners peaked strongly at dawn, was lowest during the middle of the day, and increased again slightly at dusk (Sikkel et al. 2004). Thus, evidence for a dawn peak in visits to cleaning stations associated with the dawn peak in parasite loads is taxonomically and geographically limited, with some inconsistency among studies.

An alternative explanation for a dawn peak in visits to cleaners is that it minimizes the cost, rather than maximizing the benefit of cleaning. Visiting cleaners at dawn might minimize opportunity costs by interfering least with other, more important, daily activities such as feeding and territory defense, which peak later in the day. An association with cleaners at dawn might 
also be a simple by-product of inactivity. Hosts may be quiescent and near the substratum, where cleaners typically occur, more often during the early morning period than at other times of day. These alternatives can be examined by investigating how time allocation to cleaning visits changes in response to the need for other important activities in the early morning. If visiting cleaners at dawn has priority over all other activities, it is likely to be very important. If other activities with higher priority cause fish to compensate by shifting visits to cleaners to other times, the benefit of cleaning at dawn is likely to be the actual removal of ectoparasites. However, if other activities suppress dawn visits to cleaners and the visits are not compensated by increases at other times, dawn cleaning may be of limited importance or a by-product of the location and activity of fish at that time.

The permanently territorial damselfishes provide an opportunity to examine the relationship between cleaning station visits and other components of the diel time budget. In these species, females travel to the territories of males to spawn during the first $2 \mathrm{~h}$ of daylight (Thresher 1984, Petersen 1995), creating a potential tradeoff between visits to cleaners and spawning. Because spawning does not occur every day, it is possible to compare cleaning visits on days with and without this important alternative activity in the early morning period.

As part of a study on the reproductive ecology of yellowtail damselfish in Barbados, West Indies, we recorded feeding, social and cleaning activities during timed observations of adult females over 7 time periods from dawn to dusk on non-spawning days, as well as during the early morning period on spawning days, when females spent extended periods of time away from their territory in or traveling to and from male nests. Here, we used these observations to (1) further test the prediction that interaction with cleaners peaks at dawn and (2) quantify the amount of time fish spend visiting cleaners at dawn, relative to other times of day. Having shown that cleaning peaks at dawn, we (3) quantified diel variation in feeding and aggressive interactions to assess the degree to which they might conflict and thus compete with cleaning at other times of day. Finally, we (4) compared the use of cleaners on spawning and non-spawning days, showing that females compensate for reduced opportunities to visit cleaning stations, corroborating the hypothesis that cleaning is an important activity for marine reef fishes.

\section{MATERIALS AND METHODS}

Study species. Yellowtail damselfish Microspathodon chrysurus are one of the largest damselfishes (up to $20 \mathrm{~cm}$ total length, TL) and are common on shallow coral reefs in the Caribbean and tropical Western Atlantic. They are diurnally active from about $20 \mathrm{~min}$ before sunrise to about $10 \mathrm{~min}$ after sunset. Adults of both sexes occupy non-overlapping, often contiguous territories in which they feed on epilithic microalgae and associated fauna (MacDonald 1973, Robertson 1984). Territories have shelters to which the fish retreat at night or when threatened by predators, and often include cleaning stations that territory owners and other fishes visit. Gnathiid isopods are the most common crustacean parasite on yellowtail damselfish at our study site, and ectoparasite loads are higher on females than on males (Sikkel et al. 2000).

Yellowtail damselfish territories overlap the territories of other resident herbivores, in particular smaller damselfishes Stegastes spp. and redlip blennies Ophioblennius atlanticus. Stegastes spp. reduce intrusions by non-resident heterospecific food competitors such as surgeonfishes and parrotfishes and thus reduce the costs of territory defense for yellowtail damselfish (Robertson 1984). Juvenile or subadult conspecifics may also occupy crevices or coral formations within (juveniles) or on the periphery (subadults) of adult territories.

The spatial distribution of the 2 sexes overlaps, but relative abundance of males increases with distance from the shore (MacDonald 1973, Sikkel et al. 2000). Spawning occurs on about $24 \mathrm{~d}$ per month, with a peak about 1 wk after the full moon (Robertson et al. 1990), and individual females spawn every $3 \mathrm{~d}$ (P. C. Sikkel unpubl. data). Like most other permanently territorial damselfishes, yellowtail damselfish begin to spawn about $20 \mathrm{~min}$ before sunrise at very low light levels (MacDonald 1973, Pressley 1980). In our study population, spawning normally ends about $1 \mathrm{~h}$ after sunrise, but may extend up to $0.5 \mathrm{~h}$ later. Spawning may occur during a single trip or in multiple bouts, separated by return trips to the female's territory.

Study sites. We conducted most of this study on a fringing reef (North Bellairs Reef) near the Bellairs Research Institute on the west coast of Barbados, West Indies $\left(13^{\circ} 10^{\prime} \mathrm{N}\right.$, 59 $30^{\prime} \mathrm{W}$; see map in Rakitin \& Kramer 1996) between 1 March and 9 June, 1997. Most $(>80 \%$ ) of the observations were conducted before 25 May by 2 observers (P. C. Sikkel and S. E. Herzlieb). Sunrise during the study period ranged from 05:31 to 06:14 h. Sunset ranged from 18:07 to 18:22 h. Typical of Barbados' fringing reefs, North Bellairs begins near the shoreline, with a shallow 'backreef' leading to a reef 'crest' and a 'spur and groove' zone that extends 100 to $150 \mathrm{~m}$ seaward before giving way to patch reefs and scattered coral heads and rubble. The substratum near the shore consists mostly of coral rock covered with algae. The proportion of live coral and sponge 
increases with distance from shore (Allard 1994). Chapman \& Kramer (1999) describe the fish fauna of this area. Yellowtail damselfish are abundant (up to 4 per $100 \mathrm{~m}^{2}$ ) in the spur and groove and patch reef zones to a depth of approximately $10 \mathrm{~m}$.

To determine whether the times that female damselfish spent with cleaners were similar at other locations, one of us (P. C. Sikkel) conducted observations at dawn $( \pm 15$ min relative to sunrise) and midday $( \pm 1 \mathrm{~h}$ relative to noon) at Lameshur and Haulover Bays, St. John, U.S. Virgin Islands $\left(18^{\circ} 19^{\prime} \mathrm{N}, 65^{\circ} 44^{\prime} \mathrm{W} ; \mathrm{n}=9\right)$ during July 2000, and at Mario Reef off La Parguera, Puerto Rico $\left(17^{\circ} 57^{\prime} \mathrm{N}, 67^{\circ} 03^{\prime} \mathrm{W} ; \mathrm{n}=5\right)$ from May to June 2002.

Survey methods. Damselfish activity on spawning days: During the first week of the study, we marked the nests of 65 males with flagging tape to facilitate earlymorning searches for spawning females. We surveyed the nests using an underwater light while snorkeling during the spawning period, beginning approximately $25 \mathrm{~min}$ before sunrise. When a female was found spawning, she was monitored until she completed her spawning and had returned to her territory for approximately $30 \mathrm{~min}$. Some female yellowtail damselfish revisit their territories between bouts of spawning. For females that made multiple spawning trips $(n=21)$, the observer also monitored behavior in their territories between spawning trips. The observer recorded the time spent at cleaning stations (defined below) and aggressive interactions and feeding bites of the postspawning female on her territory, noted the boundaries of the female's territory, and marked it with a numbered piece of flagging tape. We observed spawning in 50 different females.

Damselfish activity on non-spawning days: To quantify changes in behavioral activities throughout the diurnal period on non-spawning days of the lunar spawning period, we conducted focal observations, totaling $>106 \mathrm{~h}$, on 46 different females, 1 or $2 \mathrm{~d}$ after we observed them spawning. Females spawned again on the third day. Whether we conducted observations on the first or second day after spawning was determined haphazardly. We observed each female for 20 min during each of 7 time blocks (maximum of 2 fish per observer per time block per day), distributed from first light, when they become active, to dusk when they begin to enter their nocturnal shelters. The total length of time focal females were visible during the day ranged from 12.45 to $13.40 \mathrm{~h}$ (mean \pm SD: $12.99 \pm$ $0.20 \mathrm{~h}$ ). The start times (h after sunrise) of focal observations are given in Table 1. Observation periods were spaced more closely during the morning, because that was when we expected the greatest change in activity. During observations, we recorded the frequency of chases and threat displays directed toward conspecific
Table 1. Beginning of each of the seven 20 min focal observation periods of female yellowtail damselfish on non-spawning days (h after sunrise)

\begin{tabular}{|lcc|}
\hline Period no. & Mean & SD \\
\hline 1 (dawn) & 0.02 & 0.02 \\
2 & 0.67 & 0.24 \\
3 & 1.34 & 0.31 \\
4 & 3.72 & 0.34 \\
5 & 6.58 & 0.36 \\
6 & 8.86 & 0.53 \\
7 (dusk) $^{\mathrm{a}}$ & 12.05 & 0.41 \\
${ }^{\mathrm{a}}$ Ending $0.09 \mathrm{~h}( \pm 0.27)$ & before sunset \\
\hline
\end{tabular}

adults, chases of conspecific juveniles and subadults, chases of heterospecific (resident and non-resident) herbivores, chases of other heterospecifics, the frequency of feeding bites, and the amount of time visiting or 'posing' at cleaning stations. We considered a fish to be visiting a cleaning station when it remained motionless against, or a few centimeters away from, the substratum (as when being cleaned by shrimps), or when it assumed a head-up, head-down, and/or fin erect posture (as when being cleaned by small fishes). We did not distinguish between cases when the cleaner was a shrimp or a fish. We also did not distinguish among cleaner species, which included cleaner gobies Elacatinus evelynae and E. prochilos, cleaner shrimps Periclemenes pedersoni, P. yucatanicus and Stenopus hispidus, juvenile bluehead wrasses Thalassoma bifasciatum, and juvenile Spanish hogfish Bodianus rufus.

To estimate the proportion of daily cleaning during the dawn spawning period on non-spawning days, we standardized the start time of the first observation to 20 min before sunrise (when we first observed spawning females) and calculated the area under the curve defined by rates calculated during the first 3 time intervals, up to $55 \mathrm{~min}$ after sunrise (the average time of return from spawning). We divided this by the area calculated for all 7 time periods, starting from a standardized time of 20 min before sunrise, and ending at a standardized time of $12.17 \mathrm{~h}$ after sunrise. For these estimates, we used only fish for which the first observation began before sunrise $(n=21)$, to eliminate any effect of start time on rates of cleaning or feeding.

Statistical analyses. We conducted statistical analyses using SYSTAT 9.0 (Wilkinson 1999). We analyzed diel changes in behavioral activities using repeated measures ANOVA from the GLM (general linear model) option. Events or durations per 20 min observation period were used as the dependent variable. Because the assumption of sphericity (Zar 1999, Wil- 
kinson 1999) is difficult to test and often violated in repeated measures ANOVA, we examined values of Huyn-Feldt $\varepsilon$, which is not affected by violations of this assumption. In all cases, $\varepsilon$ values were consistent with $F$ values, so only the former are reported. To determine whether spawning trip patterns (single vs. multiple trips; see below) affected activity budgets, we used spawning trip category as a between-subjects factor for all but one analysis. Because most females did not have juveniles or subadults living near them, for analysis of chases of juveniles and subadults we used only those fish that had chased a juvenile during at least 1 of the 7 time periods.

To test for effects of absence from the territory during spawning on activity budgets during the postspawning period, we used paired $t$-tests to compare the amount of time that the fish spent at cleaning stations and the frequency of feeding bites and behavioral interactions immediately after the fish returned from spawning, with the average of these activities during the second and third observation periods on nonspawning days (which corresponded to the time of day when females complete spawning). For those fish that made multiple spawning trips, we similarly compared their activity rates averaged over the entire time spent in the territory between trips, and thus during the actual spawning period, with rates during the equivalent activity periods on non-spawning days (mean of first and second observation period).

For the observations on cleaning conducted at other sites, we used a 2-way repeated-measures ANOVA with Locality (Site) as a between-subjects factor. For this comparison, we were primarily interested in the relative (time of day) rather than the absolute levels of cleaning at the 2 sites, and a single analysis (rather than 2 separate analyses) allowed us to increase our sample size and the power of our analysis. Unless indicated otherwise, means are $\pm \mathrm{SD}$.

\section{RESULTS}

\section{Spawning times}

We first discovered females spawning between $20 \mathrm{~min}$ before and $58 \mathrm{~min}$ after sunrise $(3 \pm 15 \mathrm{~min}$ before sunrise). Females had completed spawning and returned to their territories by 5 to $113 \mathrm{~min}$ after sunrise $(55 \pm 21 \mathrm{~min})$. Thus, we observed females during spawning for a total of 14 to $91 \mathrm{~min}$ (51 \pm $16 \mathrm{~min})$. A total of 29 females completed spawning during a single bout, and 21 females made 2 to 9 trips $(3.7 \pm 1.8)$ to male nests, spending a total of 2.6 to $25.8 \mathrm{~min}$ in their territory between trips $(9.5 \pm$ $5.3 \mathrm{~min})$.

\section{Diel changes in cleaning on non-spawning days}

Cleaning peaked in the first sampling period of dawn, when females spent an average of $22 \%( \pm 21 \%$, range 0 to $72 \%$ ) of their time with cleaners; it declined through the early morning to $<10 \%$ and then remained approximately constant throughout the day (Fig. 1). This variation was highly significant with no significant between-subjects (spawning-trip category) or interaction terms (Table 2). During the part of the day when spawning takes place, females spent an average of $17 \%( \pm 18 \%$, range 0 to $60 \%)$ of their time visiting cleaning stations. For the subset of females for which the first observation began before sunrise, there was no correlation between the start time of the first observation and the rate of cleaning or feeding during that observation ( $p>0.15$ ). During a 12.5 h non-spawning day, females spent 84 min (95\% confidence interval: 53 to $115 \mathrm{~min})$ at cleaning stations, or $11.2 \%(7.0$ to $15.4 \%$ ) of their total time budget. An estimated $21.7 \%$ (15.6 to $28.3 \%$ ) of cleaning occurred prior to the average time of return from spawning, which represents about $10 \%$ of the day. For females observed in Puerto Rico and St. John, there was a significant effect of locality on time spent with cleaners, with females in St. John spending more time with cleaners than females in Puerto Rico $\left(F_{\text {between-subjects }}=5.962\right.$, df $=1,12, \mathrm{p}=$ 0.031). However, females spent more than 4 times the percentage of their time visiting cleaners at dawn than at midday on both St. John $(33 \pm 22$ vs. $7 \pm 6)$ and

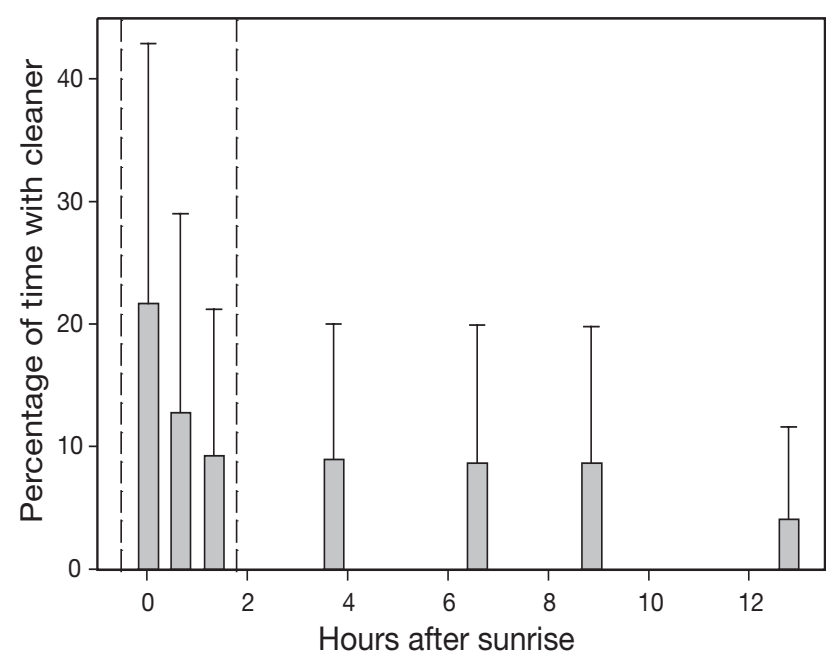

Fig. 1. Microspathodon chrysurus. Percentage of time spent with cleaners (mean $+\mathrm{SD}$ ) by adult female yellowtail damselfish $(n=46)$ during 20 min focal observations distributed over 7 time periods from dawn to dusk on non-spawning days. Mean start time of successive observations are indicated as hours after sunrise. Sunrise during the observations ranged from 05:31 to 06:14 h (mean 05:45 h), and sunset ranged from 18:07 to 18:22 h (mean 18:14 h). Vertical dashed lines indicate the range of the spawning period at the study site 
Table 2. Microspathodon chrysurus. Repeated-measures ANOVA on variation in frequency (feeding and aggressive interactions) or duration (cleaning activities in female yellowtail damselfish on non-spawning days

\begin{tabular}{|llccc|}
\hline Behavioral variable & Source & df & $F$ & $\mathrm{p}$ \\
\hline Time with cleaners & Between & 1,43 & 1.765 & 0.191 \\
& Within & 6,258 & 13.394 & $<0.001$ \\
& Interaction & 6,258 & 0.476 & 0.730 \\
Feeding bites & Between & 1,44 & 0.645 & 0.426 \\
& Within & 6,264 & 298.831 & $<0.001$ \\
& Interaction & 6,264 & 0.282 & 0.945 \\
Aggressive interactions & Between & 1,44 & 2.64 & 0.111 \\
with adult conspecifics & Within & 6,264 & 5.48 & $<0.001$ \\
& Interaction & 6,264 & 0.793 & 0.576 \\
Aggressive interactions & Within ${ }^{b}$ & 6,96 & 2.800 & 0.015 \\
with subadult and juvenile & & & & \\
conspecifics & & & & \\
Chases of non-resident & Between & 1,44 & 1.063 & 0.308 \\
herbivores & Within & 6,264 & 1.964 & 0.071 \\
& Interaction & 6,264 & 0.699 & 0.651 \\
Chases of resident & Between & 1,44 & 0.397 & 0.532 \\
herbivores & Within & 6,264 & 4.646 & 0.006 \\
& Interaction & 6,264 & 0.841 & 0.464 \\
Chases of other & Between & 1,44 & 0.037 & 0.848 \\
heterospecifics & Within & 6,264 & 2.008 & 0.065 \\
& Interaction & 6,264 & 0.481 & 0.822 \\
aBetween subjects effect $=$ spawning trip & category & (single vs. multiple \\
trips); within subjects effect & $=$ time of day & & & \\
bonly fish with neighboring & or resident juveniles and sub-adults were \\
included, and data were combined for single and multiple trip fish, so no \\
between-subjects factor was included & & & \\
\hline
\end{tabular}

Feeding rates were lowest at dawn and increased until late afternoon (Fig. 2a). Using the approach described above for cleaning, females took an estimated 3615 (95\% confidence interval: 3284 to 3947 ) bites per day. Only $1.1 \%$ (0.7 to 1.4 ) of the feeding bites on non-spawning days occurred during the time of day when spawning occurs.

Females engaged in an estimated 85 (64 to 106) chases and threat displays per day. The rate of combined aggressive interactions with conspecifics was more than double that with non-resident heterospecifics $(t=3.76, \mathrm{p}<0.001$, matched-pairs $t$-test) and more than 15 times higher than with resident herbivores $(t=6.89, \mathrm{df}=45, \mathrm{p}<0.001)$. Within the spawning periods, rates of aggression with conspecifics were lowest during the first observation period, and peaked during the second and third period. Rates subsequently declined until they rose again at dusk (Fig. 2b). The rate of chases and threats toward resident territorial herbivores was approximately equal during the 3 morning periods, dropped during the late morning and afternoon, and peaked at dusk. Chases of non-resident heterospecifics tended to peak during

Puerto Rico $(11 \pm 14$, vs. $2.6 \pm 0.6)\left(F_{\text {within-subjects }}=7.579\right.$, $\left.\mathrm{df}=1,12, \mathrm{p}=0.018 ; F_{\text {interaction }}=3.274, \mathrm{p}=0.095\right)$.

\section{Diel changes in other activities on non-spawning days}

Feeding and aggressive interactions with adult, subadult and juvenile conspecifics, and with resident herbivores varied significantly during the day at our Barbados site, with no significant between-subjects (spawning-trip category) or interaction terms (Table 2). Diel changes in aggressive interactions with nonresident herbivores and with other heterospecifics approached significance (Table 2). the first morning observation, at midday, and at dusk (Fig. 2c). Chases during the first morning observation tended to be near cleaning stations; $13.5 \%$ of all aggressive interactions occurred during the spawning period.

\section{Comparison between spawning and non-spawning activity budgets}

A summary of the number and amount of time allocated to non-spawning activities during the spawning period is presented in Table 3 . While they were at male

Table 3. Microspathodon chrysurus. Cleaning, feeding and aggressive interactions during the spawning process. Mean \pm SD and (range) are shown. -: no data

\begin{tabular}{|c|c|c|c|c|c|c|c|c|c|}
\hline \multirow{3}{*}{$\begin{array}{l}\text { Stage of spawning } \\
\text { period }\end{array}$} & \multirow{3}{*}{$\begin{array}{l}\text { Fish } \\
\mathrm{N}\end{array}$} & \multicolumn{2}{|c|}{ - Cleaning - } & \multicolumn{2}{|c|}{ - Feeding -} & \multicolumn{4}{|c|}{ Aggressive interactions } \\
\hline & & $\mathrm{N}$ & Time (min) & $\mathrm{N}$ & No. of bites & & onspecific & & erospecific \\
\hline & & & & & & $\mathrm{N}$ & No. of acts & $\mathrm{N}$ & No. of acts \\
\hline At nest & 50 & 10 & $\begin{array}{l}6.3 \pm 8.5 \\
(0.1-6.8)\end{array}$ & 0 & - & 0 & - & 0 & - \\
\hline Between trips & 21 & 12 & $\begin{array}{l}2.4 \pm 2.8 \\
(0.1-8.3)\end{array}$ & 6 & $\begin{array}{l}2.2 \pm 1.2 \\
(1.0-4.0)\end{array}$ & 13 & $\begin{array}{l}2.2 \pm 2.0 \\
(1.0-8.0)\end{array}$ & 3 & $\begin{array}{l}3.7 \pm 3.8 \\
(1.0-8.0)\end{array}$ \\
\hline $\begin{array}{l}\text { During final return } \\
\text { from spawning }\end{array}$ & 50 & 5 & $\begin{array}{l}0.23 \pm 0.06 \\
(0.17-0.30)\end{array}$ & 0 & - & 0 & - & 0 & - \\
\hline
\end{tabular}



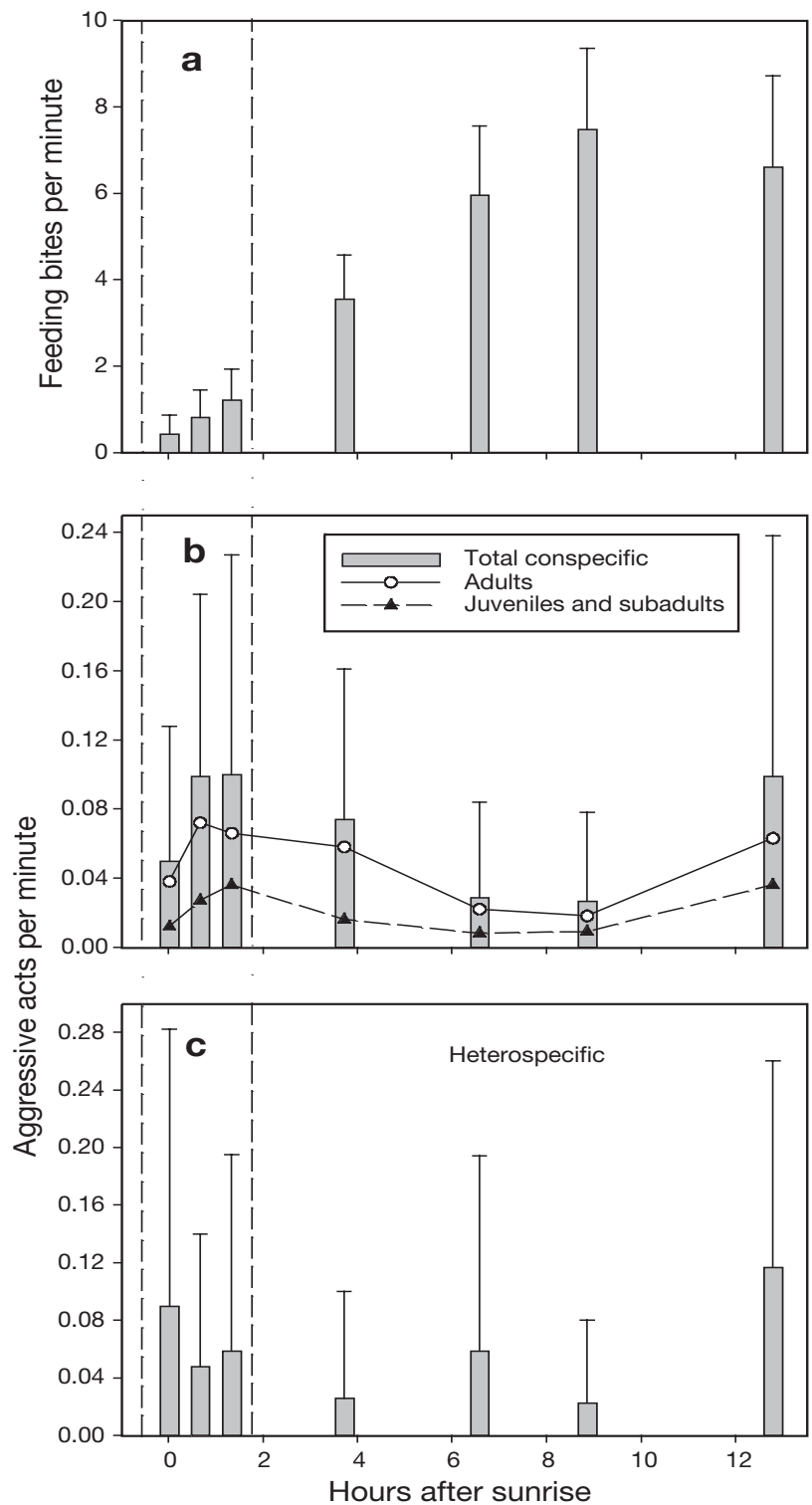

Fig. 2. Microspathodon chrysurus. (a) Rates of feeding (mean $+\mathrm{SD}$ ), (b) aggressive acts (chases and threat displays) directed toward conspecifics, (c) aggressive acts directed toward heterospecifics. Same fish and periods as in Fig. 1 nests, 10 of 50 females interrupted spawning and visited nearby cleaners. Immediately prior to these visits to cleaners, females quivered and 'chafed' (Wyman \& Walters-Wyman 1985) as if irritated. Five other females visited cleaners while traveling between the male nest and their territory. Twelve multiple-trip females visited cleaning stations in their territories between trips. In contrast, only 6 females fed. Among fish that used cleaning stations in their territory between spawning trips, the percentage of time spent at cleaning stations was significantly higher than for these same fish during the corresponding time period on non-spawning days (paired $t=2.57, \mathrm{df}=10, \mathrm{p}=0.03$, excluding 1 fish with missing data) (Table 4). Among all fish that made multiple spawning trips, including those that did not use cleaning stations, the difference was marginally nonsignificant $(t=1.905, \mathrm{df}=18, \mathrm{p}=0.073)$. Combining visits to cleaners at male nests, while traveling between the territory and the nest, and while in the territory between trips, fish observed during spawning spent an average of $1.4 \%( \pm 3.0 \%$, range 0 to $13.2 \%)$ of their spawning period visiting cleaners. This value is somewhat higher using only the subset of fish for which activity budget data are also available $(5.8 \pm 6.6 \%$, range 0 to $27.0 \%$ ), but is still approximately only $1 / 3$ of the $17 \%$ of time spent cleaning during the same period on nonspawning days, and is still highly significant (paired $t=4.30$, df = 39, p < 0.001; Fig. 3).

A total of 13 multiple-trip females engaged in chases or threats with conspecifics while in their territory between trips and only 3 chased heterospecifics (Table 3). Among females that engaged in threats and chases with conspecifics between trips, rates of aggression toward conspecifics during returns to the territory were not significantly different from rates during the corresponding time on non-spawning days $(t=1.047$, df $=11, \mathrm{p}=0.318 ;$ Table 4$)$.

After returning to the territory following the completion of spawning, the percentage of time spent at cleaning stations was nearly $70 \%$ higher than at the same time on non-spawning days (mean difference $=$

Table 4. Microspathodon chrysurus. Comparison of activities performed (a) between spawning trips, (b) during the same time on non-spawning days (c) during the postspawning period (d) during the same period on non-spawning days. For comparison (a) and (b) values are calculated only for those fish performing a given activity during the particular period. -: no data or insufficient sample size. Activities are presented as means $\pm \mathrm{SD}$ (range) $(\mathrm{N})$

\begin{tabular}{|c|c|c|c|c|}
\hline Period & $\begin{array}{l}\text { Cleaning } \\
(\% \text { of time })\end{array}$ & $\begin{array}{c}\text { Feeding } \\
\left(\text { bites } \text { min }^{-1} \text { ) }\right.\end{array}$ & $\begin{array}{l}\text { Aggressive interactions with } \\
\text { conspecifics }\left(\text { acts } \text { min }^{-1} \text { ) }\right.\end{array}$ & $\begin{array}{l}\text { Chases of hetero- } \\
\text { specifics }\left(\text { acts } \text { min }^{-1} \text { ) }\right.\end{array}$ \\
\hline (a) Between spawning trips & $24 \pm 24(4-91)(12)$ & - & $0.30 \pm 0.28(0.04-0.91)(13)$ & - \\
\hline (b) Non-spawning days & $12 \pm 13(0-41)(12)$ & - & $0.20 \pm 0.13(0.07-0.55)(13)$ & - \\
\hline (c) Post spawning & $15 \pm 17(0-63)(39)$ & $0.5 \pm 0.5(0.0-2.0)(42)$ & $0.13 \pm 0.15(0.00-0.59)(42)$ & $0.49 \pm 0.10(0.00-0.43)(42)$ \\
\hline (d) Non-spawning days & $9 \pm 11(0-36)(39)$ & $2.3 \pm 0.7(0.9-3.5)(42)$ & $0.09 \pm 0.11(0.00-0.53)(42)$ & $0.58 \pm 0.11(0.00-0.70)(42)$ \\
\hline
\end{tabular}




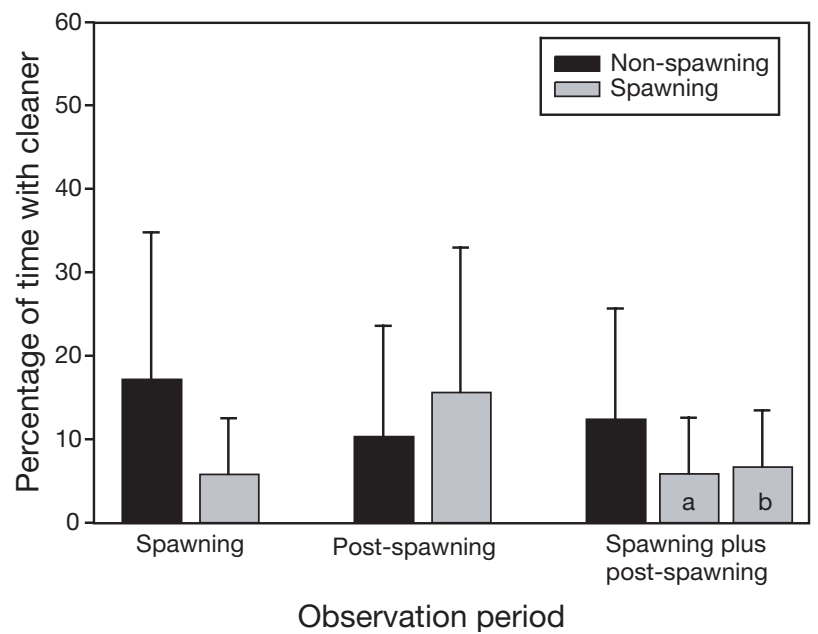

Fig. 3. Microspathodon chrysurus. Percentage of time spent on visits to cleaners by female yellowtail damselfish on mornings in which they spawned (gray bars) or did not spawn (black bars). Values are shown separately for the spawning period $(\mathrm{n}=40), 30$ min post-spawning period $(\mathrm{n}=39)$ and average of combined spawning and non-spawning period for the subset of fish observed to spawn before sunrise $(n=28)$. For spawning fish, column a excludes, and column b includes the times fish visited cleaners during spawning

$0.06 \pm 0.14 \mathrm{~min}$ per min of observation, $t=2.710, \mathrm{df}=$ $38, \mathrm{p}=0.010$ ) (Table 4; Fig. 3). To examine the degree of compensation during the 30 min period after spawning for visits to cleaners missed during spawning, we divided the total amount of time spent visiting cleaners during the post-return period by the duration of the spawning plus 30 min post return period and compared this with the rate of cleaning during the same time period on non-spawning days (Fig. 3). Because we did not know when females began to spawn, we limited this comparison to females that were discovered in nests before sunrise $(n=28$, although the percentage of time spent with cleaners differed by less than $0.5 \%$ with all females included). Visits to cleaners during the 30 min post-spawning period resulted in an overall mean of $5.6 \%( \pm 6.3 \%$, range 0 to $27.0 \%)$ of the time spent with cleaners, compared with $12.4 \%$ ( $\pm 13.3 \%$, range 0 to $42.5 \%$ ) on non-spawning days when females visited cleaners throughout the spawning and post spawning period. If time spent cleaning during spawning is included, overall rates on spawning days rise to $6.7 \%( \pm 6.6 \%$, range 0 to $17.3 \%)$, but would have been only $3.5 \%( \pm 4.8 \%$, range 0 to $17.3 \%)$ if, upon return from spawning, fish had visited cleaners at the same rate as they did during the same time on non-spawning days. If compensation during the $30 \mathrm{~min}$ after return from spawning is expressed as a percentage of the amount of cleaning that would have occurred (using rates from activity budgets and integrating over time) during each female's observed spawning time (61 $\pm 19 \mathrm{~min}$, range 24 to $111 \mathrm{~min})$ plus 30 min on non-spawning days, spawning females compensated for $68 \%( \pm 92 \%$, range 0 to $407 \%)$ of cleaning time lost during the spawning plus post-spawning period in approximately $1 / 3$ of the time. If the time spent cleaning during interruptions of spawning is included, this increases to an average of $112 \%$, but is strongly influenced by one extreme value. With this value removed, the average is $74 \%( \pm 97 \%$, range 0 to $400 \%$ ). If females did not increase their rate of interaction with cleaners upon return and interrupt spawning to visit cleaners, the amount of time spent with cleaners would have been only $23 \%( \pm 13.0 \%$, range 0 to $61 \%$ ) of the time on non-spawning days.

In contrast to cleaning, feeding bite rates following return were approximately $1 / 4$ of those at the same time on non-spawning days (mean difference: $1.7 \pm 0.7$ bites $\min ^{-1}, t=16.089, \mathrm{p}<0.001, \mathrm{df}=41$ ) (Table 4). Rates of chases and threats toward conspecifics tended to be elevated above rates over a comparable time during non-spawning, but the difference was non-significant (difference: $-0.04 \pm 0.13, t=1.776$, df $=41, \mathrm{p}=0.08$ ) (Table 4). Rates of combined heterospecific aggression were similar following spawning and during nonspawning activity budgets (difference: $-0.01 \pm 0.16, t=$ 0.304, $\mathrm{df}=41, \mathrm{p}=0.763)($ Table 4$)$.

\section{DISCUSSION}

As far as we are aware, this is the first estimate of the total diel cleaning time budgets in a marine reef-fish species. Female yellowtail damselfish in Barbados spent an average of $11 \%$, and up to $15 \%$, of their active time visiting cleaning stations on non-spawning days; observations on other islands suggest that values can be higher. These estimates do not include traveling time to cleaners. However, traveling time on nonspawning days is low, as most females have at least 1 cleaning station within or adjacent to their territories. If each feeding bite requires about $0.5 \mathrm{~s}$ and each aggressive interaction requires about $3 \mathrm{~s}$ (estimated from timed observations during a subsequent study), female yellowtail damselfish spend on average $2.4 \%$ of their time feeding and $0.7 \%$ of their time on aggression. Thus, visiting cleaners is a very important component of the time budget in comparison to other, more widely studied activities.

Cleaning varied over the daily cycle more than any other activity except feeding. It was highest around sunrise, when fish averaged over $20 \%$ of their time at cleaning stations and decreased over the course of the morning. These findings extend conclusions by Sikkel et al. (2000) - based on a comparison of morning and afternoon, and not including times before 06:45 h- 
that male and female yellowtail damselfish on 2 reefs in Barbados showed higher rates of visitation to cleaning stations in the morning. MacDonald (1973) also qualitatively described morning peaks in cleaning in yellowtail damselfish in Puerto Rico. Our findings differ from reports of no significant peaks in cleaning in 1 Australian species (Grutter et al. 2002), but appear largely consistent with less detailed observations of other Caribbean species that include an unreplicated transect survey (Chambers \& Sikkel 2002) and observations of surgeonfishes, parrotfishes, grunts, goatfishes, and 2 other damselfish species during timed focal cleaner observations (Côté \& Molloy 2003). Our findings are also similar to another study of a territorial damselfish (Sikkel et al. 2004). While the latter study included 5 rather than 7 time periods distributed from dawn to dusk, the proportion of time spent at cleaning stations in the early morning was similarly 2 to 3 times higher than other times of day. However, our findings differ from 2 of the other 3 studies in that we observed a slight decrease in association with cleaners at dusk (as opposed to an increase relative to midday).

The relatively high allocation of time to visiting cleaning stations at dawn corresponds to peak rates of emergence and infestation by gnathiids (see 'Introduction'). Because removal of gnathiids should be most beneficial soon after they infest fish, our findings are consistent with the hypothesis that diel variation in cleaner-seeking activity corresponds to diel variation in the benefits of being cleaned. While monogeneans and copepods also parasitize yellowtail damselfish at our study site and may exhibit different diel patterns of infestation, these parasites are comparatively rare (Arnal et al. 2000, Sikkel et al. 2000), and they are rarely (copepods) or never (monogeneans) found in guts of cleaner gobies (Arnal \& Côté 2000, Whiteman \& Côté 2002, P. C. Sikkel unpubl. data).

The absence of an increase in cleaning station visits at dusk may be attributable to a lower and less consistent increase in gnathiid activity at dusk than at dawn, possibly occurring only when overall levels of gnathiid activity are high (Chambers \& Sikkel 2002, Côté \& Molloy 2003, Sikkel et al. 2004). Barbados appears to have smaller gnathiid populations than other sites in the Caribbean (Arnal et al. 2000, I. M. Côté \& K. L. Cheney pers. comm.).

Because adaptive variation in any activity pattern should be influenced by the benefits relative to the costs, if cleaning interferes with other activities such as feeding (Grutter et al. 2002), it may peak at times when such interference is lowest, or show no peak at all if costs co-vary with benefits. Because of high rates of feeding early in the morning compared with other times of day, the interruption of feeding may be a significant cost of cleaning for some carnivorous species such as large wrasses (Grutter et al. 2002). In contrast, the feeding rates of yellowtail damselfish (MacDonald 1973, Robertson 1984, present study) and of herbivorous marine fishes elsewhere are low in the morning and peak in the afternoon, possibly because algal food quality is higher in the afternoon (Zemke-White et al. 2002). Thus, a dawn peak in cleaning may be favored simply because it minimizes interference with feeding. However, feeding, even at peak levels, does not appear to require enough time to significantly affect the time available for cleaning, especially given the relatively even distribution of algae within territories, which should minimize search costs. Similarly, a dawn peak in cleaning may be favored because it minimizes interference with territory defense. Because the most common cleaners in the Caribbean are small in size and strongly site-attached, hosts must approach cleaning stations and remain there while being cleaned, making cleaning incompatible with other activities that require higher mobility. In this species, conspecifics appear to be the most important territorial intruders, and experimental removal of territory owners results in a significant increase in conspecific but not heterospecific intrusion (Sikkel \& Kramer in press). Conspecific intruders feed, use cleaning stations, and may attempt to occupy part or all of the territory. Chases and threat displays between conspecifics were highest at dusk and near the end of the spawning period, and removal of owners just after the spawning period results in higher rates of conspecific intrusion than removal at first light (P. C. Sikkel \& D. L. Kramer unpubl.). Females feed at very high rates during the late afternoon until sunset, when fish begin seeking shelter. Other fishes attempt to use the same shelter sites, and yellowtail damselfish spend much of their time at dusk attempting to exclude other fish from shelter sites within their territory. Thus, on most days, the period around sunrise appears to provide a window of opportunity when both intruder pressure and feeding rates are low (Kohda 1988, Sikkel \& Kramer in press), and the average time spent on aggression and feeding is $<3 \%$ of the total activity budget. Of course, unusually high rates of intrusion may result in increased patrolling, and the rapid decrease in cleaning after sunrise could be a response to increased time spent patrolling the territory.

Dawn peaks in cleaning could also be an artifact of overall quiescent behavior during this period, in which fish are hovering near shelters occupied by cleaners. Our observations of compensatory cleaning during and immediately after spawning, along with relatively high (though marginally non-significant) rates of chases of heterospecifics near cleaning stations at dawn, suggests that dawn cleaning is important (Cheney \& Côté 2003b). Unlike other activities, the time of spawning 
overlaps strongly with the dawn peak in visitations to cleaners. Thus, females must make a tradeoff between cleaning and reproduction. Because intruder pressure and therefore the costs of absence from the territory during spawning increase with time of day and time away from the territory (P. C. Sikkel \& D. L. Kramer unpubl.), prolonging spawning can result in increased intruder pressure on the territory. Thus, if dawn cleaning were simply opportunistic, we would not expect females to prolong the spawning process by visiting cleaners at or en route to or from male nests. Yet $30 \%$ of the females we observed did so (and we observed an even higher percentage during a subsequent study at this site). Similarly, we would not expect females to increase the duration of interactions with cleaners in their territory between or after spawning trips; yet, we observed a significant increase in time spent with cleaners upon return to the territory. We observed no interruptions in spawning for feeding, nor increases in feeding and social interactions upon return. Some females returned to their territories during spawning and engaged in threats and chases with conspecifics in their territory. While trips to the territory are effective in reducing intruder pressure (Sikkel \& Kramer in press), only time spent with cleaners was elevated above normal (non-spawning) levels. In addition, we observed at least 10 cases during 1997, and during a subsequent study on spawning tactics in 1998, in which females delayed the onset of spawning well beyond the normal onset of spawning in the population (up to $1.25 \mathrm{~h}$ ); in all cases, they spent nearly the entire time at cleaning stations.

The approximately 3 -fold reduction in cleanerseeking behavior by spawning females compared with non-spawning days underscores the tradeoff between spawning and cleaning. While females compensated for reduced cleaning opportunities during spawning by significantly increasing their rate of interaction with cleaners upon return, they made up, on average, about two-thirds of the cleaning that would have occurred during the spawning and post-spawning period on a non-spawning day. However, they did so in only about one-third of the time and it is possible that increased use of cleaners continued for longer than the $30 \mathrm{~min}$ observation period.

Fitness benefits of dawn cleaning have important implications for reproductive tactics in both sexes. (1) Selection could favor females that choose males with cleaners near their nest, creating a selection pressure for males to obtain territories with cleaning stations. (2) Cleaning may impose a limit on the duration of the spawning period, if the costs of not being cleaned increase with time as parasites have more time to attach, cause tissue damage and remove fluids, and/or the benefits of cleaning decline after dawn because of decreases in infestation rate. (3) While females spawn only once every $3 \mathrm{~d}$, males may spawn and/or guard eggs every day during the lunar spawning cycle. Thus, males face a more severe tradeoff between reproduction and cleaning than females do, particularly if cleaners are far from the nest (Cheney \& Côté 2003). Males may therefore be under stronger selective pressure to choose territories with cleaners nearby and may thus compete more vigorously for them. This can limit female possession of territories with cleaners and in turn result in females experiencing heavier parasite loads. These suggestions are supported by findings in yellowtail damselfish and longfin damselfish that cleaners are more abundant in areas where males predominate, and females have higher parasite loads (Sikkel et al. 2000, Cheney \& Côté 2003).

Although many studies in behavior and ecology of marine reef fishes include observations from different times of day in an effort to examine or control for the effects of time of day on behavior, morning observations often begin well after sunrise. In this study, had we begun our observation sequence after 08:00 h, we would have entirely missed the peak cleaning period. Our finding that visiting rates at cleaning stations decline rapidly during the course of the morning highlights the importance of beginning observation series at or before sunrise.

Acknowledgements. We thank W. Hunte, L. Vermeer, S. Dorsey, P. Bear, and the staff of the Bellairs Research Institute for their support during this study. P.C.S. was supported by a Bellairs Postdoctoral Fellowship. Research expenses were supported by an NSERC research grant to D.L.K. and a MacArthur Foundation grant to W. Hunte. We thank D. Booth, K. Cheney, C. Fuller and 3 anonymous referees for constructive comments on the manuscript.

\section{LITERATURE CITED}

Allard P (1994) Changes in coral community structure in Barbados: effects of eutrophication and reduced grazing pressure. MS thesis, McGill University, Montreal

Arnal C, Côté, IM (2000) Diet of broadstripe cleaning gobies on a Barbadian reef. J Fish Biol 57:1075-1082

Arnal C, Côté IM, Sasal P, Morand S (2000) Cleaner-client interactions on a Caribbean reef: influence of correlates of parasitism. Behav Ecol Sociobiol 47:353-358

Chambers SD, Sikkel PC (2002). Diel emergence patterns of ecologically important, fish-parasitic gnathiid isopod larvae on Caribbean coral reefs. Caribbean J Sci 38:37-43

Chapman MR, Kramer DL (1999). Gradients in coral reef fish density and size across the Barbados Marine Reserve boundary: effects of reserve protection and habitat characteristics. Mar Ecol Prog Ser 181:81-96

Cheney KL, Côté IM (2001). Are Caribbean cleaning symbioses mutualistic? Costs and benefits of visiting cleaning stations to longfin damselfish. Anim Behav 62:927-933

Cheney KL, Côté IM (2003a) The ultimate effect of being 
cleaned: does ectoparasite removal have reproductive consequences for damselfish clients? Behav Ecol 14:892-896

Cheney KL, Côté IM (2003b) Indirect consequences of parental care: sex differences in ectoparasite burden and cleaner-seeking activity in longfin damselfish. Mar Ecol Prog Ser 262:267-275

Côté IM (2000) Evolution and ecology of cleaning symbioses in the sea. Oceanogr Mar Biol Annu Rev 38:311-355

Côté IM, Molloy PP (2003) Temporal variation in cleanerfish and client behaviour: does it reflect ectoparasite availability? Ethology 109:489-499

Côté IM, Arnal C, Reynolds JD (1998) Variation in posing behaviour among fish species visiting cleaning stations. J Fish Biol 53 (Suppl A):256-266

Davies AJ (1982) Further studies on Haemogregorina bigemina Laveran \& Mesnil, the marine fish Blennias pholis L., and the isopod Gnathia maxillaris Montagu. J Protozool 29:576-583

Gorlick DL, Atkins PD, Losey GS (1987) Effect of cleaning by Labroides dimidiatus (Labridae) on an ectoparasite infecting Pomacentrus vaiuli (Pomacentridae) population at Enewetak Atoll. Copeia 1987:41-45

Grutter AS (1996a) Parasite removal rates by the cleaner wrasse Labroides dimidiatus. Mar Ecol Prog Ser 130:61-70

Grutter AS (1996b) Experimental demonstration of no effect by the cleaner wrasse Labroides dimidiatus (Cuvier and Valenciennes) on host fish Pomacentrus moluccensis (Bleeker). J Exp Mar Biol Ecol 196:285-298

Grutter AS (1999) Cleaner fish really do clean. Nature 398: 672-673

Grutter AS (2003) Feeding ecology of the fish ectoparasite Gnathia sp. (Crustacea: Isopoda) from the Great Barrier Reef, and its implications for fish cleaning behaviour. Mar Ecol Prog Ser 259:295-302

Grutter AS, Hendrikz J (1999) Diurnal variation in the abundance of parasitic gnathiid isopod larvae on coral reef fish: its implications in cleaning interactions. Coral Reefs 18: 187-191.

Grutter AS, McCallum H, Lester RJG (2002) Optimising cleaning behaviour: minimising the costs and maximising ectoparasite removal. Mar Ecol Prog Ser 234:257-264

Heupel MR, Bennett MB (1999) The occurrence, distribution, and pathology associated with gnathiid isopod larvae infecting the epaulette shark, Hemiscyllium ocellatum. Int J Parasitol 29:321-330

Honma Y, Chiba A (1991) Pathological changes in the branchial chamber wall of stingrays, Dasyatis spp., associated with the presence of juvenile gnathiids (Isopoda, Crustacea). Gyobyo Kenkyu 26:9-16

Jones CM, Grutter AS (2005) Parasitic isopods (Gnathia sp.) reduce hematocrit in captive blackeye thicklip (Labridae) on the Great Barrier Reef. J Fish Biol 66:860-864

Kohda M (1988) Diurnal periodicity of spawning activity of permanently territorial damselfishes (Teleostei: Pomacentridae). Environ Biol Fish 21:91-100

Losey GS (1971) Communication between fishes in cleaning symbiosis. In: Cheng TC (ed) Aspects of the biology of symbiosis. University Park Press, Baltimore, MD, p 45-76

Losey GS (1972) The ecological importance of cleaning symbiosis. Copeia 1972:820-833

Losey GS (1979) Fish cleaning symbiosis: proximate causes of host behaviour. Anim Behav 27:669-685

Editorial responsibility: Charles Birkeland (Contributing Editor), Honolulu, Hawaii, USA
Losey GS, Margules L (1974) Cleaning symbiosis provides a positive reinforcer for fish. Science 1984:179-180

MacDonald CD (1973) Reproductive behavior and social dynamics of the yellowtail damselfish, Microspathodon chrysurus (Perciformes: Pomacentridae). MS Thesis, University of Puerto Rico, Mayaguez

Mugridge RER, Stallybrass HG (1983) A mortality of eels, Anguilla anguilla L., attributed to Gnathiidae. J Fish Biol 6:81-82

Paperna I, Por FD (1977) Preliminary data on the Gnathiidae (Isopoda) of the Northern Red Sea, the Bitter Lakes, and the Eastern Mediterranean and the biology of Gnathia piscivora n. sp. Rapp P-V Reun Comm Int Explor Sci Mer Mediterr Monaco 24:195-197

Petersen CW (1995) Male mating success and female choice in permanently territorial damselfishes. In: Sikkel PC, Petersen CW (eds) Proceedings of the Reproductive Ecology of Damselfish Symposium. Bull Mar Sci 57:690-704

Pressley PH (1980) Lunar periodicity in the spawning of yellowtail damselfish, Microspathodon chrysurus. Environ Biol Fish 5:153-159

Poulin R (1993) A cleaner perspective on cleaning symbiosis Rev Fish Biol Fish 3:75-79

Poulin R, Grutter AS (1996) Cleaning symbioses: Proximate and adaptive explanations. BioScience 46:512-517.

Rakitin A, Kramer DL (1996) Effect of a marine reserve on the distribution of coral reef fishes in Barbados. Mar Ecol Prog Ser 131:97-113

Robertson DR (1984) Cohabitation of competing territorial damselfish on a Caribbean coral reef. Ecology 65: 1121-1135

Robertson DR, Petersen CW, Brawn JD (1990) Lunar reproductive cycles of benthic-brooding reef fishes: reflections of larval biology or adult biology? Ecol Monogr 60: 311-329

Sikkel PC, Kramer DL (in press). Territory revisitation reduces intrusion during spawning trips by female yellowtail damselfish. Anim Behav

Sikkel PC, Fuller CA, Hunte W (2000) Habitat/sex differences in time at cleaning stations and ectoparasite loads in a Caribbean reef fish. Mar Ecol Prog Ser 193:191-199

Sikkel PC, Cheney KL, Côté IM (2004) In situ evidence for ectoparasites as a proximate cause for cleaning interactions in coral reef fish. Anim Behav 68:241-247

Smit NJ, Basson L, Van As JG (2003) Life cycle of the temporary fish parasite, Gnathia africana (Crustacea: Isopoda: Gnathiidae) from southern Africa. Folia Parasitol 46: 229-240

Thresher RE (1984) Reproduction in reef fishes. T.F.H. Publications, Neptune City, NJ

Whiteman EA, Côté IM (2002) Cleaning behaviour of 2 Caribbean gobies: intra and inter-specific comparisons. J Fish Biol 60:1443-1458

Wilkinson L (1999) SYSTAT 9: Statistics I. SPSS, Chicago, IL

Youngbluth MJ (1968) Aspects of the ecology and ethology of the cleaning fish, Labroides dimidiatus Randall. Z Tierpsychol 25:915-932

Zar JH 1999. Biostatistical analysis, 4th edn. Prentice Hall, Upper Saddle River, NJ

Zemke-White WL, Choat JH, Clements KD (2002) A reevaluation of the diel feeding hypothesis for marine herbivorous fishes. Mar Biol 141:571-579

Submitted: April 2, 2004; Accepted: March 31, 2005

Proofs received from author(s): June 14, 2005 